\title{
Transformation of Forms of Corruption Prevention in the Conditions of Covid-19 Pandemic in the Customs Sphere
}

\author{
Safonova N.A. \\ Bauman Moscow State Technical University (MSTU named after N.E. Bauman), 5/1, 2nd Baumanskaya street, Moscow, \\ 105005, Russia \\ Russian Customs Academy, 4, Komsomolskiy av., Moscow region, Lyubertsy, 140009, Russia \\ Corresponding author. Email: safonova-natalya-2014@mail.ru
}

\begin{abstract}
The spread of coronavirus infection in the territories of states in 2020 posed serious questions for governments, primarily concerning the life and health of citizens and ensuring the smooth functioning of medical organizations and state bodies. At the same time, the new conditions dictate specific forms and methods for the implementation of all tasks facing the state, which include combating corruption. It is obvious that the customs authorities carry out their activities around the clock, without interruption in work. The corruption risks persist even against the background of a decrease in trade and business activity as a result of the announcement of a pandemic. There is also a possibility of transition of corruption offenses into a latent state, the use of modern information technologies in the criminal sphere. This study proposes modern anticorruption measures considering the simultaneous large-scale fight against coronavirus infection.
\end{abstract}

Keywords: anti-corruption, customs authorities, innovative measures, digitalization, e-customs, coronavirus

infection.

\section{INTRODUCTION}

Corruption is a complex social and legal phenomenon that exists in any society and state, accompanying humanity throughout the entire period of its development. At the same time, the peculiarities and distinctive features of national corruption are determined by political, social, economic background, the conditions for creating a regulatory framework and the formation of the institution of public service.

Corruption refers to the problems that pose a threat to the security of the national interests of the state, turning into transnational problems in some areas of public administration. For instance, the activities of customs authorities are associated with constant interaction of the entities engaged in the foreign economic activity, which include not only individuals and legal entities of the Russian legal field, as well as the foreign citizens and organizations engaged in activities related to the movement of goods and services across the state border of the Russian Federation. Corruption distorts the normal functioning of state bodies, since the subject unit of the current governing body - an official - uses his/her powers to obtain the lucrative profit, thereby criminalizing the content of state governance.

Many scientific studies are devoted to the study of national causes and characteristics of corruption, as well as the development of specific measures to counter it within the state and in dialogue with foreign partners, the international community $[1,2,3]$. It is noted that the processes of globalization, which are the results of the exchange of goods and products, information, knowledge, cultural values, strengthening the integration of economies and societies can also be a factor contributing to corruption [4].

\section{RESEARCH METHODOLOGY}

The main methods of this study were comparative, dynamic analysis, which are based on the consideration of modern trends in the field of combating corruption on the example of customs authorities and the anti-corruption policy of customs authorities.

\section{RESEARCH RESULTS}

The activities of the customs authorities in general, and of specific officials and employees, are associated in some areas with serious corruption risks, the impact of business structures seeking to minimize or eliminate bureaucratic procedures.

Anti-corruption policy measures taken by customs authorities in accordance with the National AntiCorruption Plan for 2018-2020, approved by the Decree of the President of the Russian Federation of June 29, 2018 No. 378, and internal regulatory documents, stipulate the 
professional orientation of the personnel to comply with job descriptions, prevent the presence of subjective factors in decision-making and performance of official duties, exclusion of the possibility of misconduct in the implementation of state managerial functions, the formation of a stable legal and official position regarding corruption, conflict of interest, abuse of office.

Corruption is recognized as a socially significant phenomenon [5], which is why government bodies are making significant efforts to form, implement and develop a sustainable anti-corruption mechanism, associated not only with the detection, investigation, suppression and sanctions in relation to corruption offenses, but also preventive measures related with anti-corruption education, professional training, the formation of moral qualities, awareness of the high duty of officials who directly perform the functions of a state body. Illegal corruption acts (actions or omissions) in case of successful use of such a mechanism will be minimized or completely excluded from the activities of the relevant state bodies.

Awareness of the presence of corruption in the public service system allows, by shaping a strong political will, to find innovative ways of anti-corruption measures involving public control, ensuring transparency, accessibility of public services, forming a sustainable model of government management, when public service is perceived as the highest duty of serving the state and society.

The customs authorities are actively involved in the process of digitalization of public administration, which is recognized as an important area of anti-corruption policy measures, since it allows to implement the idea of "electronic customs" - a high level of development of the customs service in terms of information and technical support, the development of a digital platform for the functioning of customs authorities. It is the digital technologies that ensure the transparency of public administration, the effectiveness of combating corruption, when physical contacts of officials and employees of customs authorities with other participants in foreign economic activity are eliminated, the influence of subjective factors on decision-making during customs control decreases [6].

The year of 2020 has become a test for humanity for all systems of government. The spread of Covid-19 has become a general civilization problem that has affected the entire world community. Not a single state has remained aloof from issues of health care, protecting public health, preventing the spread of the virus on the territory of the state, preventing its import from the territory of foreign states, ensuring the normal functioning of all state bodies, uninterrupted provision of public services. The mortality rate from Covid-19, social problems, health problems, migration issues, movement across the border of states have become the priority issues of national and international politics $[7,8]$.

In fact, the customs authorities, participating in international trade, are vulnerable to corruption, since they interact with private stakeholders, government procurement, and business structures. During a pandemic, special attention is paid to additional measures to improve the work of customs authorities, including in the context of the spread of COVID-19, it is planned to strengthen customs control as part of the fight against the spread of coronavirus infection in Russia and other states of the Eurasian Economic Union, to identify and suppress illegal movement across the customs border of goods and services [9].

The achievements of modern science, the development of progressive scientific schools are also an additional element in the fight against corruption. A dual situation is developing in this area. On the one hand, innovative projects must have practical results for successful distribution, for example, in the provision of customs services, sustainable functioning without failures and errors. On the other hand, modern technologies are often expensive developments that require significant financial investments, while government bodies are limited by budget funding and do not always have additional funds for scientific research of innovative achievements.

This field requires the establishment of interaction between different scientific schools, discussion of achievements and the possibility of their practical application in the work of customs authorities to reduce corruption risks [10].

\section{DISCUSSION OF FINDINGS}

Customs-oriented anti-corruption measures in the context of the spread of Covid-19 shall contain the following elements.

Firstly, the shall be the professional training of officials and employees of customs authorities, based on knowledge of both Russian and international legislation. This is a set of norms containing the foundations of the constitutional system, sectoral legislation, the foundations of the organization of public service and labor activity, the norms of professional ethics of customs authorities, prohibitions and restrictions provided for by law for officials and employees of customs authorities and their family members. In addition, the Russian Federation is a party to international conventions on combating corruption (for example, the 2003 UN Convention against Corruption, the 1999 Council of Europe Criminal Law Convention on Corruption).

In addition, foreign states have national legal norms adopted to combat corruption in the implementation of customs activities in order to ensure their own national security. It is required to inform the employees and officials of customs authorities when training and improving their qualifications about the difference in the legal regulation of the same legal relations, the qualification of some actions as a corruption offense, about new regulatory legal acts of foreign states.

The modern digital educational environment, which turned out to be in demand during the pandemic, allows training, testing, and interviews on training, professional development and final certification. 
Secondly, the anti-corruption check of regulatory legal acts and their drafts adopted by the Federal Customs Service and customs authorities within the framework of their powers. The scope for corruption is precisely the regulatory gaps, especially during the development of electronic customs, when legal regulation may lag behind modern information and computer technologies. In this case, the most important specific activity of the customs authorities is tracking gaps and the development of relevant modern rules and regulations.

Thirdly, improving the sector of electronic provision of customs services. Creation of a unified database of participants in foreign economic activity with a personal account for access to electronic office work, tracking in real time the passage of documents and the provision of services, excluding physical contact between employees and officials of customs authorities and participants in foreign economic activity. This promising direction for the development of the customs sector in our state has already been highly appreciated.

Fourthly, analysis of the experience of foreign states in combating corruption, exchange of theoretical and practical bases. Thus, the successful experience of foreign countries with highly developed economies, which include South Korea and Singapore, makes it possible to talk about effective combating corruption at all levels of government. At the same time, the development, implementation, modification of anti-corruption measures in these states does not stop, but develops through the adoption of active measures to combat corruption, moral regulation of public processes along with the reform of the corporate and financial sectors $[11,12,13,14]$. The task of completely stopping the corruption practices in a society can be solved only for a certain point in time, it is important to note that this does not guarantee that corruption will not appear in the future.

Fifthly, the formation of public opinion not only when informing about the condemnation of persons involved in a corruption scandal, but also the formation of intolerance to corrupt behavior in society at the level of general perception of both a negative and dangerous social phenomenon, and at the private level, when corrupt behavior is recognized as unacceptable for solving their own problems with private interests. Particular attention should be paid to such issues during a pandemic, when priority attention is paid to maintaining health, work, financial well-being, both personal and close circle of people.

It should be noted that during a pandemic, the media should correctly cover events of a corrupt nature that take place in the field of public administration, not forgetting about the fundamental principles and ideas of Russian law, and about the norms of professional journalistic ethics. For example, it is a violation of human rights when the terms "corrupt" or "criminal" are used before a conviction is issued and enforced by a court. "Loud" headlines are actively used to attract the attention of the audience to television and radio broadcasting, Internet publications, news feeds, but at the same time, the perception of the event is distorted, an accusatory bias and distrust of the state and state bodies is formed. An approach to the coverage of events in the state, which forms the idea of the connection between official duties and the replacement of a civil service position, and the possibility of abuse of official powers to satisfy one's own selfish interests, is not acceptable. On the contrary, the formation of public opinion about the legal status of the civil service should be inherently connected with the idea of voluntary restriction of one's own rights in order to achieve a high goal serving the society and the state.

Sixthly, finding new elements for the development and improvement of the digital platform for the activities of customs authorities. The modern period of development of society and the state is marked by the active use of virtual remote capabilities. Accessibility, high speed of data processing, minimum financial, time costs, access to information through a personal account from anywhere in the world, even distribution of the load on customs authorities within the state, development of economic sectors, increasing competitiveness, expanding the possibility of public and individual control, reducing the level corruption - these results are expected from the digital transformation of the public administration. For example, the actively developing technology for the distribution of databases has economic and organizational advantages in the field of combating corruption - an array of documentation and descriptions of actions taken, the results of interaction can be reflected in the form of a blockchain. It is also possible to organize the exchange of unclassified data with other states that are customs partners of the Russian Federation.

At the same time, actively developing a digital platform for government management in general, and actively using digital technologies in the activities of customs authorities, one should also take into account the mandatory observance of the rights and freedoms of citizens and organizations, conducting an educational campaign to ensure the confidence of the population and organizations in new information and computer technologies, explaining how to protect data entered in electronic form for obtaining customs services. For example, some scientific studies are aimed at identifying the opinion of Internet users about the state's control of Internet traffic, as a result of which the state has unlimited opportunities to intervene and regulate all spheres of society. And the results obtained indicate that the participants of virtual electronic communication relations in most cases have a negative attitude to the increase in the share of control over the Internet traffic [15].

Seventhly, material and social support for civil servants and customs officials, encouragement of further training in the implementation of professional activities.

The skills of working with information and telecommunication technologies in government bodies shall be developed ahead of similar skills by participants in foreign economic activity. This is not only the possession of knowledge, skills in using an electronic platform, databases, correct and complete display of information, understanding the connections between individual blocks of information, interaction with other state bodies and 
participants in customs actions, but also ensuring the cybersecurity of all resources using digital technologies, development and implementation of secure technological solutions, interaction and exchange of experience with other subjects of foreign economic activity, ensuring the national interests of the state and national security.

Highly qualified specialists, possessing knowledge and practical skills in the provision of customs services, and ensuring the security of the use of information technologies are always required in the structure of state bodies. However, low salaries, mismatch between inflation and wage growth rates entail "turnover" of personnel in the customs service. Together with strict restrictions and prohibitions, prescriptions, instructions, intensity of working conditions, high mental and physical stress, the outflow of qualified personnel from the customs authorities does not stop. This negative factor in the implementation of public administration leads to the loss of trained and with practical experience of work, leads to time costs for the search and training of a new employee, the redistribution of responsibilities between the existing staff, interferes with the consolidation and formation of an effective team, reduces motivation in the performance of official duties, worsens the morale of the entire team and individual employee.

In such conditions, with the spread of coronavirus infection and dissatisfaction with the conditions of work, a surge in the mood of professional burnout and professional deformation of the personality is possible, which, in turn, has a bad effect on combating corruption, since the priority of professional and ethical qualities, awareness of official duty, honor, the reputation of a government agency fades into the background or is completely discredited.

\section{CONCLUSION}

Thus, the activities of the state to develop, implement and improve anti-corruption measures, undertaken before the pandemic, should not stop against the background of an exacerbation of the situation with the virus, the accumulation of major efforts in the fight for the health of the population, for maintaining the normal functioning of state bodies and the provision of public services, preventing the spread of the virus, its import from the territories of other states.

On the contrary, the attention of state bodies, especially customs, should be focused on preventing the spread of corruption offenses in special anti-epidemiological conditions for the movement of goods and services across the border of the Russian Federation, including on the strict and steady formation of a professional culture with high moral potential aimed at combating corruption as among officials and employees of customs authorities, as well as among Russian and foreign participants in foreign economic activity.

The real level of corruption in the customs authorities is expressed in the implementation of public administrative functions in the customs sphere.
The conceptual position of each official and employee of the customs authorities, including the fundamental principles of professional and legal culture on the prevention of the use of official powers for the sake of personal interests and needs, on the priority of official duty, on strict observance of the requirements of the legislation governing relations between public authorities and participants in foreign economic customs activities must be maintained at a high level, ensuring continuity, consistency in the application of anti-corruption measures.

\section{REFERENCES}

[1] Silveira L. D. O. Can the wto bring more teeth to the global anticorruption agenda? (2019) Journal of World Trade, 53(1), p. 129-151.

[2] Knights, M. Explaining away corruption in premodern Britain (2018) Social Philosophy and Policy, 35(2), p. 94-117.

[3] Epaphra, M., Massawe, J. Corruption, governance and tax revenues in Africa (2017) Business and Economic Horizons, 13(4), p. 439-467.

[4] Beesley, C. Globalization and corruption in postSoviet countries: Perverse effects of economic openness (2015), Eurasian Geography and Economics, 56(2), p. $170-192$

[5] V. Demidov, D. Mokhorov, A. Mokhorova, S. Kosarev. Anti-Corruption Policy As A Condition For Improving Public Officials Professional Culture. https://doi.org/10.15405/epsbs.2019.12.102.

[6] Safonova N.A. Tsifrovizatsiya $\mathrm{v}$ razvitii antikorruptsionnykh mer / Global'naya Sbornik nauchnykh stateĭ po itogam raboty shestogo kruglogo stola s mezhdunarodnym uchastiyem, 2020, s.163-165.

[7] Miller, H.V., Ripepi, M., Ernstes, A.M., Peguero, A.A. Immigration Policy and Justice in the Era of COVID-19 (2020). American Journal of Criminal Justice, 45(4), p. 793-809

[8] S. M. Eliseev*, E. A. Kovtun, S. D. Savin, V. A. Glykhikh. Perception Of Anti-Corruption Policy Of The Russian Federation In The Russian Consciousness. https://doi.org/10.15405/epsbs.2020.03.02.2

[9] Rabotu tamozhennykh organov YEES v usloviyakh pandemii COVID-19 usovershenstvuyut / URL: https://rg.ru/2020/05/12/rabotu-tamozhennyh-organovees-v-usloviiah-pandemii-covid-19-

usovershenstvuiut.html 
[10] Safonova N.A. Ispol'zovaniye sovremennykh tekhnologiy $\mathrm{v}$ protivodeystvii korruptsii $\mathrm{v}$ tamozhennykh organakh // Lomonosovskiye chteniya: Materialy yezhegodnoĭ nauchnor konferentsii MGU (22-24 aprelya 2020 goda, g. Sevastopol'), pod red. O.A. Shpyrko, Sevastopol': Filial MGU v g. Sevastopole, 2020 / URL: https://sev.msu.ru/wpcontent/uploads/2020/06/Lomonosovskie-chtenija.pdf (data obrashcheniya 04.09.2020).

[11] Liu, H., Wang, T.-Y. China and the "Singapore Model": Perspectives from mid-level cadres and implications for transnational knowledge transfer (2018) China Quarterly 236, p. 988-1011. DOI: 10.1017/S0305741018000462).

[12] Shunayev Aleksey Mikhaylovich Opyt bor'by s korruptsiyey v Yuzhnoy Koreye i Singapure // Upravlencheskoye konsul'tirovaniye. 2018. №3 (111). S. 65-71.

[13] Safonova N.A., Bayush A.YU. Yuzhnaya Koreya i indeks vospriyatiya korruptsii // Nauka i biznes: puti razvitiya, 2019, № 10 (100), s. 102-107.

[14] Jong-sung You. Development of control of corruption in South Korea. GIGA German Institute of Global and Area Studies. 28 May 2015.

[15] Akhmadieva, R.Sh., Ignatova, L.N., Bolkina, G.I., Soloviev A.A., Gagloev D.V., Korotkova, M.V., Burenina, V.I. An attitude of citizens to state control over the internet traffic (2018). Eurasian Journal of Analytical Chemistry 13(1),em82. 